\title{
Tiedonkeruun traditiot ja osallistuminen vapaan sivistystyön opintoihin
}

\section{Vertailtavina Suomi, Ruotsi ja Tanska}

\author{
Tutkitun tiedon roolia yhteiskunnallisessa päätöksenteossa \\ on viime vuosina pohdittu paljon ja edellytetty päätösten \\ pohjautuvan luotettavaan tietoon. Suomessa aikuiskoulutusta \\ koskevan tunnisteellisen tiedon puute haittaa erityisesti vapaan \\ sivistystyön kehittämistä.
}

SUOMESSA JA MUISSA POHJOISMAISSA koulutuksenjärjestäjät raportoivat julkisen rahoituksen piirissä olevasta toiminnastaan säädösten mukaisesti. Aikuiskoulutuksesta kerätään hallinnossa kertyvää rekisteritietoa sekä kohdistettua kyselytietoa. Kertynyt tieto koostetaan tilastoiksi, joita hyödynnetään päätöksenteon eri vaiheissa tavoitteiden saavuttamisen todentamiseen ja koulutuspolitiikan perustelemiseen.

Selvitimme EduMAP-tutkimushankkeessa (www.uta.fi/edumap) aikuiskoulutukseen osallistumista koskevan tiedon saatavuutta Euroopan unionin jäsenmaissa. Tavoitteena oli tutkia, millä ehdoin aikuiskoulutus tavoittaa heikoimmassa asemassa olevia nuoria aktiivista kansalaisuutta ja yhteiskunnallista osallisuutta vahvistavien opintojen pariin.
Suomen-osatutkimus kohdistui tiedon saatavuuteen Ruotsissa, Suomessa ja Tanskassa. Ruotsissa ja Tanskassa aikuiskoulutuksen osallistujista kootaan kattavampaa tietoa kuin Suomessa. Keskeinen Suomen tietovarantoa koskeva havainto on, että vapaan sivistystyön osallistujista puuttuu henkilöpohjainen tieto.

\section{AIKUISKOULUTUKSEN ERIARVOISUUS JA TASA-ARVON TOTEUTUMISEN ONGELMA TUTKIMUKSEN VALOSSA}

Tilastot ja tutkimustulokset osoittavat, että aikuiskoulutus tavoittaa parhaiten korkeasti koulutetut ja hyvässä työmarkkina-asemassa olevat, kun taas matalasti koulutetut tai heikossa työmarkkina-asemassa olevat 
eivät aikuisenakaan hakeudu opiskelemaan yhtä aktiivisesti (esim. European Commission 2016, 137; OECD 2017, 18-19; Statistiska Centralbyrån (SCB); Silvennoinen 2002; Silvennoinen \& Lindberg 2015) Tilastokeskuksen määräajoin toteuttama Aikuiskoulutustutkimus osoittaa, että työssäkäyvät osallistuvat koulutukseen useammin kuin työttömät, korkeaasteen koulutuksen suorittaneet useammin kuin perusasteen koulutuksen suorittaneet ja toimihenkilöt useammin kuin työntekijät (Niemi ym. 2014, 21-23; SCB 2014). Tutkijat ovat selittäneet osallistumisaktiivisuuden eroja esimerkiksi osallistumisen esteillä, joita on jäsennelty tilannetta, asenteita ja rakenteita koskeviin tekijöihin (Rubenson \& Desjardins 2009). Yleisemmin yhteiskunnallisten resurssien epätasaista jakautumista selitetään etujen kasautumisen mekanismilla (Merton 1968). Sosiaaliset mekanismit vaikuttavat myös koulutuksen kertymiseen tai koulutuksesta syrjäytymiseen (Silvennoinen 2002, 187). Korkeasti koulutetut hyötyvät koulutuksen tuottamasta lisäarvosta ja näyttäisivät luottavan siihen, että kouluttautuminen kannattaa sen myötä aukeavien laajentuvien työtilaisuuksien myötä (Kilpi-Jakonen ym. 2012).

Aikuiskoulutukseen osallistumisen eroja on tutkittu laajasti. EduMAP-tutkimushankkeen puitteissa halusimme selvittää asiaa tiedontuotannon näkökulmasta. Tarkastelimme koulutusresurssien kohdentumisen ja tiedonkeruun mekanismien kytköstä. Selvitimme, mitä tietoa aikuiskoulutukseen osallistumisesta kerätään ja miten se kerätään, mistä lähteistä tieto on peräisin ja miten saatavissa olevaa tietoa voidaan hyödyntää tutkimuksessa ja päätöksenteossa.

Huomasimme, kuten tutkijat aiemminkin (esim. Field 2000), että aikuiskoulutuksen järjestämistavat ja tehtäväkentät ovat moninaisia, ja siksi aikuisten koulutukseen liittyvät kysymykset ovat erityisen vaikeasti hallinnoitava yhteiskuntapolitiikan alue. Unionin jäsenmaiden erilaisten historiallisten kehityskulkujen tuottamat kansalliset koulutusjärjestelmät ja aikuiskoulutuksen ratkaisumallit ovat niin kirjavia, että niiden vertailu on hankalaa. Jäsenmaiden erilaiset tilastokulttuurit vaikeuttavat jossain määrin maiden keskinäistä vertailua, mutta siitä huolimatta vertailukelpoista dataa pyritään tuottamaan päätöksenteon tueksi (Desrosières 2007).

\section{KOULUTUKSEN TARKASTUSKÄYTÄNNÖSTÄ NORMI- JA RESURSSIOHJAUKSEEN: LAILLISUUDEN JA TILINPIDON SEURANTA}

Suomessa julkisin varoin rahoitettua koulutusta ohjataan normiperusteisesti laeilla ja asetuksilla. Toiminnan viranomaisohjaus toteutuu valtakunnallisten opetussuunnitelmien, koulutuksen järjestämislupien ja oppilaitosten ylläpitämislupien sekä resurssijaon kautta. Koulutuksen tarkastuskäytännöstä luovuttiin 1980-luvulla (Pirttiniemi 2010), eikä opetustoimeen siten kohdistu säännönmukaista tarkastusmenettelyä. Viranomaisten toimeenpanemat toiminnan tarkastukset koskevat tyypillisesti joko kanteluita tai tilinpidon yhteydessä todettuja rahoituksen epäselvyyksiä (mt. 255).

Rahoittajat ja kansallinen tilastoviranomainen, Tilastokeskus, seuraavat koulutuksen toteutumista kokoamalla järjestäjiltä tietoa koulutuksesta ja siihen osallistuneista. Koulutuksenjärjestäjät ovat velvollisia raportoimaan toiminnastaan rahoituksen myöntäjän edellyttämällä tavalla (Laki opetus- ja kulttuuritoimen rahoituksesta 58. \$). Tiedonkeruun yksi tarkoitus on varmentaa, että rahoitus on käytetty juuri siihen kohteeseen, johon se on osoitettu. Toimintaa kuvaava numeerinen aineisto, opiskelijamäärät ja koulutuksen toteutusta ilmentävät tunnusluvut tuottavat tietoa, jota hyödynnetään julkisten varojen käytön seurannassa, toiminnan suunnittelussa ja päätöksenteossa.

\section{RAHOITUSKANAVAT, RESURSSIEN KOHDISTUMISEN SEURANTA JA VAIKUTTAVUUDEN ARVIOINTI}

Aikuiskoulutuksen järjestämistä rahoitetaan useasta julkisesta ja yksityisestä lähteestä. Yritysten tai opiskelijoiden suorittamat maksut kattavat osan kustannuksista. Ministeriöiden hallinnoimien kansallisten budjettivarojen lisäksi tarjolla on sekä kansallista että Euroopan unionin projektirahoitusta. Kukin rahoittaja soveltaa erilaisia jakoperusteita ja seurantamekanismeja varojensa hallinnointiin.

Vapaan sivistystyön, aikuisten perusopetuksen ja ammatillisen koulutuksen julkinen rahoitus perustuu säädöksiin. Opetushallinnon rahoitus edellyttää 
SUOMEN LAINSÄÄDÄNTÖ EI

VELVOITA OSALLISTUMAAN

KYSELYTUTKIMUKSIIN.

lisäksi järjestäjäkohtaista ylläpitämislupaa. Työvoimahallinnon resurssijako pohjaa puolestaan avoimeen hankintamenettelyyn. Koulutuksen rahoitus myönnetään järjestäjälle siten joko ylläpitämisluvan tai kilpailutuksen perusteella.

Valtionosuusrahoituksen jakoperusteet pohjautuvat eri koulutusmuotojen ja -alojen kustannusten ja suoritteiden yksityiskohtaisiin laskelmiin. Laskennassa käytettyjä suoritteita ovat esimerkiksi koulutuksen yksikköhinta ja osallistujien märä. Yksikköhinnan laskennassa käytetty tekninen suure, esimerkiksi opetustunti, opiskelijavuorokausi, opiskelijatyöpäivä, opiskelijaviikko, vaihtelee koulutusmuodoittain ja -aloittain ja mukailee toiminnan luonnetta (yksityiskohtaiset laskentaperusteet ks. Opetushallitus 2017.) Budjettivarojen lisäksi koulutustoimintaa järjestetään projektirahoituksella. Rahoitusta saadakseen hakijan on täytettävä rahoittajan määrittämät hakukriteerit ja mukautettava toimintaansa hakukohteena olevan ohjelman mukaiseksi.

Rahoituksen saajat raportoivat toiminnasta rahoittajien edellyttämällä tavalla. Rahoittaja seuraa toiminnan ja tilinpidon laillisuutta suoritteiden laskentaan perustuvan raportoinnin avulla. Raportointitieto ei sellaisenaan yksin riitä mittaamaan toiminnan vaikuttavuutta, toisin sanoen arvioimaan toiminnan tarkoituksen toteutumista säädösten mukaisesti.

Vaikuttavuuden arvioinnin kannalta on tärkeää huomata, että kun tavoitteena on edistää työllisyyttä ja vastata elinkeinoelämän osaamistarpeisiin (Laki ammatillisesta koulutuksesta 2. \$), aikuiskoulutus on sidoksissa koulutuspolitiikan lisäksi muihin yhteiskunnan aloihin, kuten työ- ja elinkeinopolitiikkaan. Kun tavoite on edistää yhteiskunnan eheyttä ja tasa-arvoa (Laki vapaasta sivistystyöstä 1. \$), aikuiskoulutus kytkeytyy hyvinvointipolitiikkaan ja yleiseen turvallisuuteen.
Aikuisopiskelijoilla oppimisen ja opiskelun vaikutukset voivat olla laajempia kuin henkilökohtaiseen hyvinvointiin liittyviä. Aikuisen elämään kuuluu huolehtia myös perheen ja läheisten toimeentulosta ja hyvinvoinnista (Manninen \& Luukannel 2008, 70.) Koulutuksen vaikuttavuutta voidaan arvioida numeerisen tiedon pohjalta pitkittäistutkimuksella, mikäli osallistujista on saatavissa henkilöpohjaista tietoa. Tutkintotavoitteisesta koulutuksesta ja työllisyydestä seurantaa onkin tehty kattavasti (esim. Kilpi-Jakonen ym. 2012; Boeren \& Holford 2016). Vapaasta sivistystyöstä vastaavaa tutkimusta ei Suomessa nykyisellään ole mahdollista tehdä (OKM 2014, 20).

\section{REKISTERITIETO VERSUS KYSELYTIETO}

Aikuiskoulutusta koskevan tiedon tuotanto kytkeytyy hallinnon määrittämiin suoritteisiin, kuten rahoituksen perusteiden laskentaan ja koulutuksen toteutuman seurantaan. Ruotsissa, Suomessa ja Tanskassa väestöä ja yhteiskunnan toimintaa koskevat tilastot pohjautuvat suurelta osin niin sanottuun rekisteritietoon. Se on dataa, jota on alkujaan kerätty hallinnon tarpeisiin (Valkonen ym. 1998). Hallinnollisia tietorekistereitä ovat esimerkiksi väestörekisteri ja verotustiedot. Oppilaitosten toiminnan hallinnointiin ja seurantaan tarvitsemat tiedot opiskelijoistaan muodostavat henkilörekisterin. Kun oppilaitos esimerkiksi kerää opintomaksuja, kirjanpitoon ja asiakasrekisteriin merkitään tieto maksajasta ja suoritetusta maksusta. Opetuksen suunnittelussa tarvitaan tietoa opiskelijoista ja opiskelijamääristä, jotta käytettävissä olevat resurssit, opetustilat ja henkilöstön työaika saadaan kohdistettua järkevällä tavalla.

Työttömän työnhakijan tulee rekisteröityä työ- ja elinkeinohallinnon (TE-hallinto) asiakasrekisteriin ollakseen oikeutettu TE-toimiston palveluihin ja työttömyysturvaan. Hallinnon osoittamista toimenpiteistä, kuten työvoimakoulutukseen osallistumisesta, kertyy tietoa järjestelmään. Kansaneläkelaitoksen (Kela) asiakasrekisteriin puolestaan kertyy tietoa henkilöistä, jotka ovat saaneet esimerkiksi eläkettä tai sairauspäivärahaa vamman tai sairauden perusteella, työmarkkinatukea työttömyyden perusteella 
SUOMESSA EI KER $\ddot{A} T \ddot{A}$

HENKILÖPOHJAISTA TIETOA

VAPAAN SIVISTYSTYÖN

OSALLISTUJISTA.

tai opintotukea opiskelun tueksi. Rekisteridata kertyy perustoiminnan sivutuotteena, se on kattavaa, eikä erillistä kysymisen tai vastaamisen vaivaa synny.

Koulutuksen tietovarantoa kootaan tilastollisia tarkoituksia varten myös erilaisin kyselyin. Esimerkiksi taloudellisen yhteistyön ja kehityksen järjestö OECD, Euroopan unionin tilastoviranomainen Eurostat ja kansallisella tasolla Suomen Tilastokeskus, Opetushallitus ja Kansallinen koulutuksen arviointikeskus (Karvi) ovat toteuttaneet kyselytutkimuksia aikuiskoulutuksesta tai sisällyttäneet sitä koskevia kysymyksiä laajempia aihepiirejä koskeviin kyselyihin.

Laajoin kyselyaineistoin on selvitetty esimerkiksi vapaan sivistystyön koulutuksen opiskelijoiden näkemyksiä aikuisopiskelun hyödyistä ja vaikuttavuudesta Suomessa (Manninen \& Luukannel 2008) ja eri EU-maissa (BeLL 2014). Kyselytutkimukset eivät kata rekisteritiedon tapaan koko väestöä vaan perustuvat aina otokseen. Esimerkiksi Suomen vuoden 2012 Aikuiskoulutustutkimukseen poimittiin 18-69-vuotiaiden maassa pysyvästi asuvien perusjoukosta otannalla 6088 henkilöä, ja lopullinen kyselyyn vastanneiden määrä oli 4114 .

Suomen lainsäädäntö ei velvoita osallistumaan kyselytutkimuksiin, joten otokseen valituilla on oikeus kieltäytyä vastaamasta. Vastauskatoa voivat aiheuttaa kielivaikeudet ja se, että henkilöä ei tavoiteta. Kyselyille on tyypillistä, että vastaukset ovat muistinvaraista tietoa, eikä kyselyn tekijällä ole mahdollisuutta tarkistaa tiedon paikkansapitävyyttä. Otoksesta voidaan jo lähtökohtaisesti rajata pois joitakin väestöryhmiä, kuten Aikuiskoulutustutkimuksessa laitoksissa asuva väestö (Niemi ym. 2014, 158-166.)

Hallinnon rekisterit ja kyselyt tuottavat numeerista tietoa, jota hyödynnetään tilastojen laadinnassa. Tilastotiedon tarkoitus on yksinkertaistaa ja muuntaa yhteismitalliseksi muutoin vaikeasti mitattavaa todellisuutta. Se on moderneissa yhteiskunnissa hallinnon ja päätöksenteon tarvitsemaa vertailtavaa dataa, jonka avulla muun muassa kuvaillaan asioiden tilaa, luodaan strategisia tavoitteita ja seurataan niiden toteutumista. Rekisteriaineistot ja kyselyt kertovat kuitenkin ainoastaan niistä seikoista, joista tietoa kirjataan rekistereihin tai joihin kyselyt kohdistuvat (Alastalo 2018.) Pohjoismainen tilastokulttuuri perustuu pitkälti hallinnon sivutuotteena syntyvään rekisteridataan. Koulutusta koskevassa tiedonkeruussa Suomen vapaa sivistystyö on kiinnostava poikkeus: osallistujista ei koota henkilöpohjaista tietoa, profilitietoakin on kerätty ainoastaan satunnaisesti kyselyin.

\section{TUTKIMUSTA VARTEN HANKITUT REKISTERIAINEISTOT}

Saadaksemme selville, mitä tietoa haavoittuvassa asemassa olevien nuorten osallistumisesta aikuiskoulutukseen on saatavissa, hankimme tutkimusluvat useiden rekisterinpitäjien aineistoihin, jotka sisältävät tunnisteellista tietoa haavoittuvissa elämäntilanteissa olevista henkilöistä, esimerkiksi toimeentulotuen saajista. Tutkimusluvat haettiin Kelan, Terveyden ja hyvinvoinnin laitoksen, työ- ja elinkeinoministeriön (TEM), Rikossseuraamuslaitoksen ja Tilastokeskuksen aineistoihin, jotka sisältävät tunnisteellista tietoa pitkäaikaissairauden tai vamman vuoksi tukeen oikeutetuista, toimeentulotuen saajista, työttömistä työnhakijoista ja rikosseuraamusasiakkaista. Tietoa aikuiskoulutukseen osallistumisesta löytyi Kelan, TEM:ön ja Tilastokeskuksen seuraavista aineistoista: opintotukirekisteri, TE-hallinnon asiakasrekisteri sekä opiskelija- ja tutkintorekisterit.

Kun rekisteriaineistoja verrataan valmiisiin tilastoaineistoihin, niiden etuna on mahdollisuus analysoida tekijöiden välisiä riippuvuuksia käyttämällä havaintoyksikkönä yksilöä (Valkonen ym. 1998, 15). Henkilötietoja sisältävän tutkimusaineiston käsittelyssä on erityisen huolellisesti otettava huomioon eettiset näkökohdat. Analysoitava aineisto ei kuitenkaan enää muodosta henkilörekisteriä, mikäli tunnistetiedot, kuten nimi ja henkilötunnus, on poistettu, eikä tietoja voi liittää tai tunnisteita palauttaa yksilöitävissä olevaan 
Ruotsissa TIEDOT

VÄESTÖN KOULUTUKSEEN

OSALLISTUMISESTA OVAT

AVOIMESTI SAATAVILLA.

henkilöön (Kleemola 1998, 23.) Tietosuojasyistä Tilastokeskus poisti tunnistetiedot hankkimastamme rekisteriaineistosta ja korvasi henkilötunnukset pseudotunnisteella, jonka avulla samaa henkilöä koskevat eri rekisterinpitäjien tiedot voidaan yhdistää. Tällä tavoin on mahdollista selvittää, miten koulutukseen osallistuminen vaihtelee taustamuuttujien mukaan ja erilaisissa yhteiskunnan tukiin oikeuttavissa elämäntilanteissa. EduMAP-tutkimushankkeessa halusimme lähinnä perehtyä aineiston käytettävyyteen ja tietovarantoon, joten hankimme tarkoitukseen soveltuvan poikkileikkausaineiston. Pitkittäisaineistojen avulla olisi mahdollista seurata saman henkilön toimintaa koulutuksen jälkeen ja tarkastella esimerkiksi tuen tarpeita ja työmarkkinoille sijoittumista.

\section{TIETOJEN SAATAVUUS VAPAAN SIVISTYSTYÖN OSALLISTUJISTA}

Suomessa henkilöpohjaista tunnisteellista tietoa koulutukseen osallistumisesta on saatavilla muutamista lähteistä. Tutkintoon johtavasta koulutuksesta on tietoa Tilastokeskuksen opiskelijarekisterissä, työvoimakoulutusta koskevat tiedot ovat TE-hallinnon asiakasrekisterissä ja opintotukeen oikeutetut kansanopistojen pitkäkestoisen koulutuksen opiskelijat Kelan opintotukirekisterissä.

Toisin kuin Ruotsissa ja Tanskassa, Suomessa ei kerätä henkilöpohjaista tietoa vapaan sivistystyön osallistujista. Opetusministeriö selvitti tiedonkeruun yhteydessä vuosina 2004-06 vapaan sivistystyön opiskelijoiden profiilitietoa iän, sukupuolen, koulutustaustan ja pääasiallisen toiminnan osalta (OKM 2014, 10). Käytäntö ei kuitenkaan ole vakiintunut vuosittaiseen raportointiin. Vaikka oppilaitoksessa yleensä tiedetään tarkasti, keitä opiskelijat ovat ja kuinka monta opiskelijaa osallistuu millekin opintojaksolle, tieto jää koulutuksenjärjestäjälle, eikä sitä raportoida rahoittajille.

Tiedonkeruun menettelyiden vuoksi henkilöpohjainen tieto vapaan sivistystyön osallistujien puuttuu tilastoviranomaiselta, jolloin tilastollisesti on varminta osallistujien sijasta laskea osallistumistapauksia (OKM 2011, 12; Seppänen 2014). Vuotuinen vapaan sivistystyön opiskelijoiden kokonaismäärä on siten tulkinnanvarainen. Esimerkiksi Tilastokeskuksen laskennan perusteella vuoden 2012 netto-opiskelijamääräksi ilmoitettiin 980000 (Saloheimo 2015), kun taas kyselypohjaisen Aikuiskoulutustutkimuksen kautta saadut tiedot ja oppilaitosten raportoimat osallistumiskerrat yhdistämällä osallistujia arvioitiin olleen noin 520000 (Manninen 2015, 35).

Vapaan sivistystyön osalta on todettu, että kattavien tilastotietojen puuttuminen ja tutkimustiedon vähäisyys vaikeuttavat toiminnan seurantaa ja arviointia (Vaherva ym. 2006, 14-15; Valtiontalouden tarkastusvirasto 2004). Tutkimustiedon vähäisyyden ja numeerisen tiedon puuttumisen lisäksi on merkille pantavaa, että vapaata sivistystyötä kuvaavat käsitteet ja määritelmät eivät ole tutkintotavoitteisen koulutuksen tavoin täsmällisiä tai yksiselitteisiä (Manninen 2017).

Ruotsissa tiedot väestön koulutukseen osallistumisesta ovat avoimesti saatavilla sikäläisen tilastoviranomaisen, Statistiska centralbyrånin, verkkosivuilta (www.scb.se). Eri hallinnonalojen aineisto on koottu taulukoihin, joista opiskelijoita koskeva taustatieto on helposti haettavissa ikävuosittain ja kaikissa koulutusmuodoissa (Statistiska centralbyrån). Vapaan sivistystyön resurssijaon ja tiedonkeruun tehtävä on Ruotsissa ulkoistettu viranomaisilta Folkbildningsrådetille. Se on aatteellinen yhdistys, jonka jäsenjärjestöt edustavat Ruotsin opintokeskuksia ja kansanopistoja. Opintokeskuksia edustaa yhteisjärjestö Studieförbunden i samverkan, kansanopistoja kaksi järjestöä: kunnallisten toimijoiden Sveriges Kommuner och Landsting ja järjestötaustaisia kansanopistoja edustava Rörelsefolkhögskolornas intresseorganisation. 
RAHOITUSMEKANISMIT

\section{SAATTAVAT V ̈̈LILLISESTI \\ EST ̈̈̈̈ KOULUTUKSEN}

\section{TASA-ARVON TOTEUTUMISEN.}

Ruotsin eduskunta ja hallitus ovat osoittaneet Folkbildningsrådetille määrätyt viranomaistehtävät. Se vastaa koulutukseen osoitetun valtion rahoituksen jakamisesta sekä seuraa ja arvioi kansanopistojen ja opintokeskusten toimintaa, kuten koostaa vuosittain tiedot oppilaitosten toiminnasta ja opiskelijoista ja raportoi niiden pohjalta eduskunnalle, hallitukselle ja jäsenorganisaatioille toiminnan toteutumasta (Folkbildningsrådet 2014.)

Vuonna 2013 toteutettiin esimerkiksi kansanopistojen opiskelijoita koskeva selvitys, joka sisälsi tietoa siitä, kuinka monta toimintarajoitteista opiskelijaa osallistui kansanopistojen kursseille. Raporttiin koottiin yksityiskohtainen tieto kaikkien liikuntaesteisten, aistivammaisten, kuulo- ja näkövammaisten, kehitysvammaisten ja muiden kohderyhmään kuuluvien opiskelijoiden lukumääristä kansanopistojen kursseilla (Olofsson \& Germundsson 2015, 32-36.)

Tanskassa aikuiskoulutukseen osallistumisesta kerätään tietoa eri hallinnonaloilta, ja Danmarks statistik, Tanskan kansallinen tilastoviranomainen vastaa koulutuksenjärjestäjiltä saatujen tietojen koostamisesta ja julkistamisesta. Tietoa on saatavilla yksilöidysti seitsemässä kategoriassa: yleiset ja valmistavat kurssit (VUC), kansanopistot, tanskan kielen opetus ulkomaalaisille, ammatillinen aikuiskoulutus $(A M U)$, avoin opetus ammatillisessa koulutuksessa, avoin opetus ammattikorkeakouluissa ja avoimen yliopiston opetus. Erilaisten koulutusten suoritteita on laskennallisesti yhdenmukaistettu niin, että kokopäiväisesti opiskelevien määristä voidaan tuottaa vertailukelpoista tietoa aikuiskoulutuksen muodosta riippumatta (Statistics Denmark 2016, 3-4.)

Sekä Ruotsissa että Tanskassa tutkijat voivat hakea rekisteritietojen käyttölupaa keskitettyä palvelua hyödyntäen. Tunnisteellinen henkilöpohjainen tieto kaikkien koulutusmuotojen opiskelijoista mahdollistaa eri rekisterien sisältämän tiedon yhdistämisen sekä yksilökohtaisen seurannan.

\section{RAHOITUSMALLIEN SEURAUKSET}

Aikuiskoulutuksen monipolvisen rahoituksen etuja ovat joustavuus ja tarjonnan monipuolisuus. Elinikäisen oppimisen toimintaympäristöä ja päätöksentekoa tutkinut John Field (2000) on kuitenkin kiinnittänyt huomiota hallinnon monimutkaistumiseen ja huoleen sen seurauksista, joista yksi on koulutuksenjärjestäjien lisääntynyt työtaakka. Hallinnollisen työn lisääntyminen vaikuttaa monin tavoin oppilaitosten työhön (mt. 258). Kunkin rahoittajan soveltamat säädökset ja toiminnan seuranta edellyttävät järjestäjiltä kykyä mukautua rahoittajien menettelytapoihin ja omaksua erilaisia hallinnon käytäntöjä. Hankintamenettelyt, toiminnan mukauttaminen projektirahoituksen saamiseksi sekä raportointi ja seuranta kuluttavat niukkoja työvoimaresursseja. Lisääntynyt hallinnoinnin tarve vaatii voimavaroja ja saattaa vähentää niitä oppilaitosten ohjaus- ja opetustyöltä, jolla toimijat pyrkivät asettamiinsa kasvatus- ja oppimistavoitteisiin.

Rahoitusmekanismit saattavat pitää yllä hallinnollisia käytäntöjä ja rakenteita, jotka estävät koulutuksen tasa-arvon toteutumisen. Lisääntynyt hallinnointivastuu voi lisätä alueellista epätasa-arvoa, kun väestökeskittymien alueilla ja suurissa yksiköissä on enemmän resursseja käytössään ja siten kykyä monimutkaisen rahoitusjärjestelmän yhä tehokkaampaan hyödyntämiseen. Puhtaasti taloudellisen hyödyn näkökulmasta menestyksekkäintä olisi rekrytoida suurin mahdollinen määrä opiskelijoita, järjestää suuren yksikköhinnan koulutusta vähäisillä resursseilla ja valita opiskelijoita, jotka varmimmin suorittavat koulutuksen loppuun.

Vapaassa sivistystyössä rahoitusjärjestelmän on havaittu ohjaavan opistoja reaktiiviseen toimintamalliin, joka perustuu olemassa olevien asiakkaiden tarpeiden ja kysynnän tyydyttämiseen (Manninen 2015, 36). Julkisesti rahoitetun toiminnan tulisi kuitenkin palvella kansalaisia tasapuolisesti, jolloin yleis- 
hyödyllisten palvelujen suuntaaminen kapealle kohderyhmälle näyttäytyy ongelmallisena (Valkonen, 2015, 228).

\section{TIETÄMÄTTÖMYYDEN JA NÄKYMÄTTÖMYYDEN SEURAUKSET}

Lainsäädäntö määrittää aikuiskoulutuksen tarkoituksen niin sanotussa tarkoituspykälässä. Vapaan sivistystyön tarkoitus on järjestää yhteiskunnan eheyttä, tasa-arvoa ja aktiivista kansalaisuutta tukevaa koulutusta. Oppilaitoksen koulutustehtävä ja muut koulutuksen järjestämisen ehdot voidaan edelleen määritellä opetusministeriön myöntämässä järjestäjäkohtaisessa luvassa. Ilman henkilöpohjaista osallistujatietoa on kuitenkin vaikeata seurata tai todentaa, miten tasa-arvoisesti koulutus kohdentuu.

Yksi vapaan sivistystyön toimijoiden jakama huoli koskee juuri sivistyksellisen tasa-arvopyrkimyksen ja markkinaehtoisen toimintamallin välistä tasapainoilua. Lainsäätäjä ja rahoittaja voivat ohjeistaa ja suunnata toimintaa haluamaansa suuntaan, mutta kentän toimijoiden on ratkaistava ne käytännön ongelmat, joita ristiriidan kanssa tasapainottelu vaatii. Käytännössä koulutuksenjärjestäjät usein keskittyvät niihin aktiivisiin opiskelijoihin, jotka jo ovat toiminnan piirissä. Koulutuksellisen tasa-arvon edistämisen tavoite jää toteutumatta, kun rajalliset voimavarat edellyttävät markkinaehtoista toimintatapaa (Valkonen, 2015.) Olisi kiinnostavaa selvittää vielä tarkemmin koulutuksenjärjestäjien soveltamia rahoituksen varmistamisen strategioita, ja arvioida, ovatko rahoitusmekanismit osaltaan vaikuttaneet "helppojen" opiskelijoiden suosimiseen vaikeammin tavoitettavien ja enemmän tukea tarvitsevien kustannuksella.

Tämän tutkimuksen puitteissa keskustelin usean kansalaisopiston edustajan kanssa mahdollisuudesta saada henkilöpohjaisia osallistujatietoja mukaan EduMAP-tutkimuksen aineistoon. Esittelin tiedonkeruuta koskevia ajatuksia Vapaan sivistystyön päivillä elokuussa 2017. Olin yhteydessä myös Vapaa Sivistystyö ry:n edustajiin kysyäkseni, miksi vuonna 2015 tehtäväksi suunniteltu tiedonkeruu jäi toteuttamatta. Keskustelujen pohjalta henkilöpohjaisen tiedonkeruun vastustaminen ei näytä liittyvän ainoastaan kysymyksiin henkilötietojen arkaluonteisuudesta vaan myös koulutuksenjärjestäjien haluttomuuteen jakaa tietoa ja pelkoon lisääntyvästä työtaakasta.

Tutkimustulos vahvistaa aiemmin esitettyä huolta tiedontuotannon puutteista Suomessa. Päätöksenteossa henkilöpohjaisen tiedon puuttuminen vapaan sivistystyön opiskelijoista merkitsee tietynlaista tietämättömyyttä. Kun koulutusta koskevista tilastoista puuttuu vertailukelpoinen numeerinen tieto, toiminta on näkymätöntä. Tietoa joudutaan keräämään erillisselvityksin, mikä ei kuitenkaan aina ole mahdollista nopeatempoisessa lainsäädäntötyössä.

Resurssien kohdentamisen näkökulmasta näkymättömyys on voinut olla yksi tekijä, joka on vaikuttanut vapaan sivistystyön toimijoiden kokemukseen, että rahanjaossa on hävitty ammatilliselle koulutukselle ja epäonnistuttu vakuuttamaan päättäjät toiminnan tarpeellisuudesta (esim. Sihvonen 1996, 228). Kun tutkintotavoitteisesta koulutuksesta on eksaktit tunnusluvut ja tietoa siitä, keitä opiskelijat ovat, toiminnan syrjimättömyyttä ja koulutuksen tasa-arvoista kohdentumista voidaan arvioida monin kriteerein, kuten alueellisen kattavuuden, opiskelijoiden sosioekonomisen taustan tai sukupuolen kannalta. Vapaan sivistystyön koulutuksesta vastaavat tunnusluvut puuttuvat, jolloin toiminnasta on voinut muodostua julkisuudessa jopa hieman mystinen kuva.

Valtiontalouden tarkastusvirasto (2004) totesi raportissaan kansanopistojen toiminnasta, että toiminnan arvioinnin pohjaksi tarvittavaa tietopohjaa ei ole, eikä toimintaan kohdistu systemaattista ja jatkuvaa seurantaa. Arvioinnin mahdollistavaa tietojärjestelmää ei ole käytössä, vaan toiminnan seuranta perustuu lähinnä tilinpidon tunnuslukuihin. Tarkastusviraston raportissa kiinnitettiin huomiota lisäksi vapaan sivistystyön avoimen hakeutumisen periaatteen ja joidenkin opistojen järjestämislupiin kirjatun rajatun kohderyhmän väliseen ristiriitaan. (mt. 44.)

Vapaan sivistystyön tiedonkeruun ongelmia selvittäneen työryhmän (OKM 2011) tavoite oli kehittää tiedonkeruun mekanismeja ja tiedontuotantoa. Raportissaan työryhmä ehdotti siirtymistä henkilöpohjaiseen tiedonkeruuseen, mutta Opintokeskusseura ry ja Suomen Kansanopistoyhdistys ry esittivät ehdotukseen eriäviä kantoja vetoamalla muun muassa tiedon 
arkaluonteisuuteen (mt. 22). Työryhmän suositus henkilöpohjaiseen tiedonkeruuseen siirtymisestä ei ole toistaiseksi toteutunut.

Tutkimushavaintojen valossa jäimme pohtimaan, mihin esitetty tulkinta tiedon arkaluonteisuudesta perustuu. Onko tieto suomalaiseen vapaaseen sivistystyöhön osallistumisesta niin arkaluonteista suhteutettuna vaikka toimeentulotuen saajien ja rikosseuraamusasiakkaiden tietoihin, että sitä ei voisi käyttää hallinnon ja tutkimuksen tarkoituksiin?

Työryhmäesityksen vastustusta voisi tulkita edunvalvonnan edellyttämäksi vastarinnaksi. Koulutuksenjärjestäjien kannalta vastarinta ei ole perusteltua, jos tiedonkeruun traditioista kiinni pitäminen ja henkilöpohjaisesta tiedonkeruusta kieltäytyminen tuottaa tietämättömyyttä, joka kytkeytyy resurssien niukkuuteen ja epätasaiseen jakautumiseen.

Henkilöpohjaiseen tiedonkeruuseen siirtyminen vapaan sivistystyön osallistujista yhdenmukaistaisi koulutuksen tiedontuotannon käytäntöjä. Numeerinen tieto vahvistaisi keinoja tehdä työtä näkyväksi

Tulokset saatiin Euroopan unionin rahoituksen tuella. EduMAP on Euroopan unionin Horizon 2020 -tutkimusja innovaatio-ohjelman rahoittama projekti. ja todentaa tavoitteiden toteutumista, mikä auttaisi vapaata sivistystyötä perustelemaan erityistä sivistystehtäväänsä.

Tunnisteellinen tieto olisi hyödynnettävissä sekä tutkimukseen että toiminnan legitimointiin. Henkilöpohjainen tieto vapaan sivistystyön opiskelijoista mahdollistaisi tilastoviranomaiselle eri hallinnonalan tietojen yhdistämisen. Päättäjät voisivat seurata resurssien kohdentumista, tasa-arvon ja syrjimättömyyden toteutumista sekä arvioida koulutuksen vaikuttavuutta monin kriteerein. Hallinnollista työtaakkaa olisi mahdollista jopa vähentää, kun erillisselvitysten tekemisen tarve vähenisi.

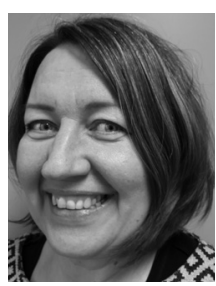

\section{PAULA KUUSIPALO}

KM, tutkija

kasvatustieteiden tiedekunta

Tampereen yliopisto

\section{LÄHTEET}

Alastalo M. (2018). Eurostat: Making Europe commensurate and comparable. Teoksessa Heiskala, R. \& Aro, J. (toim.) Policy Design in the European Union an Empire of Shopkeepers in the Making? London: Palgrave, 87-110.

BeLL (2014). Benefits of Lifelong Learning. Final Report. Public part. http://bell-project.eu_dev (25.4.2015).

Boeren E. \& Holford J. (2016). Vocationalism Varies (a Lot); A 12-Country Multivariate Analysis of Participation in Formal Adult Learning. Adult Education Quarterly 66 (2), 120-142.

Desrosières, A. (2007). Surveys versus administrative records: reflections on the duality of statistical sources. Courrier des statistiques, English series 13.

European Commission (2016). Employment and Social Developments in Europe 2015. Luxembourg: Publications Office of the EU.
Field, J. (2000). Governing the Ungovernable. Why Lifelong Learning Policies Promise so Much Yet Deliver so Little. Educational Management \& Administration 28 (3), 249-261.

Folkbildningsrådet (2014). Folkbildningens betydelse för samhället. Stockholm: Folkbildningsrådet.

Kilpi-Jakonen, E., Vono de Vilhena, D., Kosyakova, Y., Stenberg, A. \& Blossfeld, H.-P. (2012). The impact of formal adult education on the likelihood of being employed: A comparative overview. Studies of Transition States and Societies 4 (1), 48-68.

Kleemola, M. (1998). Tietosuojavaatimukset henkilörekistereihin perustuvissa tieteellisissä tutkimuksissa. Teoksessa Valkonen T., Koskinen S. \& Martelin T. Rekisteriaineistot yhteiskunta- ja terveystutkimuksessa. Helsinki: Gaudeamus, 21-38. 
Laki alueiden kehittämisestä ja rakennerahastotoiminnan hallinnoinnista 17.1.2014/7.

Laki ammatillisesta koulutuksesta 11.8.2017/531.

Laki opetus- ja kulttuuritoimen rahoituksesta 29.12.2009/1705.

Laki vapaasta sivistystyöstä 21.8.1998/632 .

Manninen, J. (2017). Empirical and genealogical analysis of non-vocational adult education in Europe. International Review of Education, 63 (3), 319-340.

Manninen, J. (2015). Mikä nakertaa vapaan sivistystyön vapautta, työtä ja sivistävyyttä? Teoksessa Pätäri J., Turunen A. \& Sivenius A. (toim.) Sivistystyön vapaus ja vastuu, 30-37. Helsinki: VST.

Manninen, J. \& Luukannel, S. (2008). Omaehtoisen aikuisopiskelun vaikutukset. Vapaan sivistystyön opintojen merkitys ja vaikutukset aikuisten elämässä. Helsinki: VSY.

Merton, R. K. (1968). The Matthew effect in science. Science 159 (3810), 56-63. http://www.garfield. library.upenn.edu/merton/matthew1.pdf (10.8.2017).

Niemi, H., Ruuskanen, T. \& Seppänen, T. (2014). Osallistuminen aikuiskoulutukseen vuonna 2012. Helsinki: Tilastokeskus.

OECD (2017). Understanding the Socio-economic Divide in Europe. Background report. http://www.oecd.org/ inclusive-growth/about/centre-for-opportunity-andequality/cope-divide-europe-2017-background-report. pdf (12.5.2017).

OKM (2011). Vapaan sivistystyön tilasto- ja tietopohjan kehittämishanke. http://minedu.fi/julkaisu?pubid=UR N:ISBN:978-952-263-075-9 (2.9.2017).

Olofsson J. \& Germundsson P. (2015). Steget vidare. Undersökning bland folkhögskolans deltagare 2013. Stockholm: Folkbildningsrådet.

Opetushallitus (2017). Opetus- ja kulttuuritoimen rahoitus - yksikköhintojen ja rahoituksen määräytyminen vuonna 2017. Helsinki: Opetushallitus.

Pirttiniemi, J. (2010). Kouluylihallituksen tarkastustoimesta opetushallituksen informaatioohjaukseen. Teoksessa Kauranne J. ym. (toim.) Ajankohtainen Uno Cygnaeus. Uno Cygnaeuksen juhlavuosi 2010. Helsinki: Suomen kasvatushistoriallinen seura, 243-257.

Rubenson, K. \& Desjardins, R. (2009). The Impact of Welfare State Regimes on Barriers to Participation in Adult Education. Adult Education Quarterly 59 (3), 187-207.
Saloheimo, L. (2015). Vapaan sivistystyön palvelurakenne. Oppilaitosten koulutustarjonta. Helsinki: VST. http:// www.sivistystyo.fi/doc/julkaisut/NST_raportti_ palvelurakenne_25021015.pdf (24.11.2017).

Seppänen, T. (2014). Vapaa sivistystyö on merkittävä osa aikuiskoulutusta. Hyvinvointikatsaus 3/2014. Helsinki: Tilastokeskus.

Sihvonen, J. (1996). Sivistystä kaikille vai valituille? Väitöskirja. Kasvatustieteiden tiedekunta. Tampere: Tampereen yliopisto.

Silvennoinen, H. (2002). Koulutus marginalisaation hallintana. Helsinki: Gaudeamus.

Silvennoinen, H. \& Lindberg, M. (2015). Aikuiskoulutukseen osallistuminen Suomessa. Aikuiskasvatus 35 (4), 266-285.

Statistiska Centralbyrån. Befolkning 16-64 år efter kön, ålder, typ av studiedeltagande, utbildningsnivå och studiemedelsutnyttjande under höstterminen. År 1993-2015. http://www.statistikdatabasen scb.se/pxweb/sv/ssd/START__UF__UF0507/ StudiedeltagandeR/?rxid=86abd797-7854-45649150-c9b06ae3ab07 (24.11.2017).

Statistiska Centralbyrån (2014). Vuxnas deltagande i utbildning 2011/2012. Örebro: SCB.

Statistics Denmark (2016). Documentation of statistics for Courses and Adult Education 2016. Copenhagen: Statistics Denmark. http://www.dst.dk/ en/Statistik/emner/uddannelse-og-viden/kurser-ogvoksenuddannelse/alle-kurser (27.11.2017).

Vaherva, T., Malinen, A., Moisio, A., Raivola, R., Salo, P., Kantasalmi, K., Kamppi P. \& Silvennoinen, H. (2006). Vapaan sivistystyön oppilaitosrakenne ja palvelukyky. Jyväskylä: Koulutuksen arviointineuvosto.

Valkonen, E. (2015). "Me myymme ja markkinoimme kursseja" Markkinaorientaation piirteet kansalaisopistoissa. Dissertations in Education, Humanities, and Theology: 79. Joensuu: Itä-Suomen yliopisto

Valkonen, T., Koskinen, S. \& Martelin, T. (1998). Rekisteriaineistot yhteiskunta- ja terveystutkimuksessa. Helsinki: Gaudeamus.

Valtiontalouden tarkastusvirasto (2004). Kansanopistojärjestelmä. Tarkastuskertomus 81/2004. 